\title{
Ontogenic expression of a Cyl actin fusion gene injected into sea urchin
} eggs

\author{
KAREN S. KATULA*, BARBARA R. HOUGH-EVANS, ROY J. BRITTEN and ERIC H. DAVIDSON
}

Division of Biology, Callformia Institute of Technology, Pasadena, Califormia 91125, USA

* Present address: Biology Department, West Virginia Unıversity. Morgantown, West Virginia 26506, USA

\section{Summary}

The $5^{\prime}$ terminus of the $C y I$ actin gene transcription unit of Strongylocentrotus purpuratus was located by primer extension and other procedures, and the flanking upstream region was partially sequenced and mapped. A fusion gene was constructed containing about $2.5 \mathrm{~kb}$ of $5^{\prime}$ flanking sequence, the transcribed leader sequence, and the first few codons of the $\mathrm{CyI}$ gene ligated to the bacterial gene coding for chloramphenicol acetyl transferase (CAT). This was microinjected into the cytoplasm of $S$. purpuratus eggs, and CAT enzyme activity was measured at various stages of embryonic development. CAT synthesis was activated between 10 and $14 \mathrm{~h}$ postfertilization, the same time at which newly synthesized transcripts of the endogenous $C y I$ gene first appear. The exogenous CyI-CAT fusion DNA replicated actively during cleavage, as observed previously for other DNAs injected into sea urchin egg cytoplasm. Thus the absence of CAT activity prior to $10 \mathrm{~h}$ postfertilization could not be due to insufficient $\mathrm{CyI} \cdot \mathrm{CAT}$ genes. The amounts of CAT enzyme produced by embryos bearing $\mathrm{CyI}$ - CAT deletions that lack various regions of the CyI sequence were measured. As little as 254 nucleotides of upstream $C y I$ sequence suffice for correct temporal activation of the fusion construct, although the level of CAT enzyme produced in embryos bearing any deletion retaining $<\mathbf{8 5 0}$ nucleotides of upstream sequence was significantly lowered compared to controls bearing the complete $\mathrm{CyI} \cdot \mathrm{CAT}$ fusion construct.

Key words: gene transfer, cytoskeletal actin, developmental regulation, sea urchin, $C y I$.

\section{Introduction}

Cloned genes microinjected into the cytoplasm of sea urchin eggs by the methods described previousiy (McMahon et al. 1985; Flytzanis et al. 1985) may be expressed appropriately during embryonic development. Most studies to date have been carried out with histone genes and with the CyIIIa cytoskeletal actin gene of Strongylocentrotus purpuratus (Davidson et al. 1985; Flytzanis, Britten \& Davidson, 1986, 1987; Hough-Evans et al. 1987). The Cyllla gene is normally activated at $10-12 \mathrm{~h}$ postfertilization in this species (Shott, Lee, Britten \& Davidson, 1984; Cox et al. 1986) and exclusively in precursors of aboral ectoderm cells, to which its transcripts are confined throughout embryonic development (Angerer \& Davidson, 1984; Cox et al. 1986). We showed earlier that after injection into unfertilized eggs a fusion gene construct containing CyIIIa $5^{\prime}$ flanking sequences ligated to sequences coding for the bacterial enzyme chloramphenicol acetyl transferase (CAT) is regulated normally, at least to a first approximation. That is, CAT enzyme begins to be synthesized in embryos deriving from the injected eggs at the stage of development when the endogenous CyIIIa gene is activated and there ensues at least a 100 -fold accumulation of CAT enzyme protein (Flytzanis et al. 1987). The amount of CAT mRNA produced is at maximum a few times greater than the normal amount of CyIIIa mRNA. Moreover, in $S$. purpuratus embryos bearing the CyIIIa.CAT fusion gene, CAT mRNA is observed only in the aboral ectoderm cells (HoughEvans et al. 1987).

In this paper, we describe experiments carried out with another CAT fusion, containing putative regulatory elements of the $C y I$ rather than the CyIIIa cytoskeletal actin gene. Our objects were to determine whether correct temporal regulation would 
again be observed on injection into $S$. purpuratus egg cytoplasm of a construct including CyI control sequences; and to locate these sequences in the gene map, at least to a coarse level of resolution. This initially required the determination of the $5^{\prime}$ end of the $C y I$ gene, which had not previously been reported. The $C y /$ gene is activated at about the same stage of development as is the CyIIla gene (Shott et al. 1984; Cox et al. 1986). However, by in situ hybridization it has been demonstrated that CyI actin message is present in a different set of cells, which in late embryos is essentially complementary to the set of cells expressing the CyIIIa gene. Thus at the pluteus stage $C y I$ transcripts appear in the oral ectoderm and much of the gut, regions which are devoid of detectable $C y I I I a$ transcripts, and $C y I$ transcripts are absent from the aboral ectoderm where are located all of the CyIIIa transcripts (Angerer \& Davidson, 1984; Cox et al. 1986). At the early blastula stage, when newly synthesized transcripts of both genes first appear, the CyI RNAs accumulate in all regions of the embryo. In contrast, at this stage newly synthesized $C y I I I a$ transcripts are asymmetrically confined to the precursors of the future aboral ectoderm, then located on one side of the spherical embryo. $C y I$ transcripts are also found in primary and secondary mesenchyme cells in gastrula-stage embryos, but ultimately disappear from these cell types, as they do from the presumptive aboral ectoderm. In respect to the succession of cell types in which the gene is activated, the spatial pattern of $\mathrm{CyI}$ gene expression is thus completely distinct from that of the CyIIIa gene. It has been pointed out (Lee et al. 1984; Shott et al. 1984) that the cis-regulatory $C y I$ sequences are likely to be located in the vicinity of the gene or within it, since this gene is closely linked to another cytoskeletal actin gene, CyIla, which displays a third pattern of lineagespecific cellular expression in the embryo (Cox et al. 1986). The cytoskeletal actins encoded by these differently utilized genes may perform diverse functions within the embryonic cells. Thus from the spatial and temporal distribution of its transcripts Cox et al. (1986) surmised that the CyI gene produces a cytoskeletal actin required in dividing cells, while the CyIIIa actin is believed to contribute to the structural characteristics of the relatively rigid, single cell thick aboral ectoderm wall of the larva (Akhurst et al. 1987). The important point for our present purposes is that although the time course of activation of the $C y I$ and CyIIIa genes is similar, at least some of the molecular regulatory signals to which they respond must be distinct, since at any given stage they are expressed in different sets of cells.

\section{Materials and methods}

\section{DNA sequencing}

The DNA sequences reported were obtained by the dideoxy chain termination method (Sanger, Nicklen \& Coulson, 1977) using the single-strand DNA phage M13 vectors mp10 and mp11 (Messing, Crea \& Seeburg, 1981).

\section{S1 nuclease protection assays}

The various DNA fragments chosen for $S 1$ analysis were subcloned into mp10 and mp11 vectors so that the strand complementary to the RNA could be transcribed. Preparation of the single-strand probes was essentially as described by $\mathrm{Hu} \&$ Messing (1982), and $\mathrm{S} 1$ nuclease digestions were carried out by a method slightly modified from Berk \& Sharp (1977). Details of these procedures as utilized in this work can be found in Akhurst et al. (1987).

\section{Primer extension}

The 25 nucleotide (nt) primer used for the primer extension reaction was synthesized in the Caltech Microchemical Facility. The primer was labelled with ${ }^{32} \mathrm{P}$ at the $5^{\prime}$ end using T4 polynucleotide kinase (IBI). The primer fragment was gel purified on an $8 \mathrm{~m}$-urea, $10 \%$ acrylamide gel (19:1 acrylamide:bisacrylamide). The labelled primer was hybridized to $5 \mu \mathrm{g}$ of poly $(\mathrm{A})$-containing RNA isolated from $48 \mathrm{~h}$ embryos, or to $5 \mu \mathrm{g}$ of yeast tRNA, in a total volume of $10 \mu \mathrm{l}$, consisting of $100 \mathrm{~mm}$-Tris, $\mathrm{pH} 8.6,10 \mathrm{~mm}-\mathrm{MgCl}$, $140 \mathrm{~mm}-\mathrm{KCl}$, and $20 \mathrm{~mm}-\beta$-mercaptoethanol. After hybridization overnight at $37^{\circ} \mathrm{C}$, the reactions were diluted to $25 \mu \mathrm{l}$ in the same buffer, containing 30 units of RNasin (Promega Biotec), 15 units of reverse transcriptase (Life Sciences, Inc.), $10 \mathrm{~mm}$ each of deoxynucleotide triphosphate (dATP, dCTP, dGTP, dTTP), and $1 \mu \mathrm{g}$ of actinomycin D. After incubation at $37^{\circ} \mathrm{C}$ for $1 \mathrm{~h}$, the samples were extracted with phenol and with Sevag solution, (24: 1 chloroform: isoamyl alcohol) and precipitated at $-20^{\circ} \mathrm{C}$. The precipitated samples were spun down in a microfuge, washed with $70 \%$ ethanol and with $95 \%$ ethanol, and then air dried. The samples were resuspended in $6 \mu \mathrm{l}$ of sequencing gel buffer ( $90 \%$ formamide, $10 \mathrm{~mm}-\mathrm{NaOH}, 10 \mathrm{~mm}-\mathrm{EDTA}, 0.25 \%$ bromophenol blue, $0.25 \%$ xylene-cyanol) and loaded on an $8 \mathrm{M}$-urea-10\% acrylamide gel for electrophoresis.

\section{Construction of the Cyl.CAT fusion gene}

Cyl 5 ' upstream sequences were obtained from the plasmid pCIpN5 (Fig. 1), which includes about $6 \mathrm{~kb}$ of $C y /$ sequence $5^{\prime}$ to the CyI ATG signal, plus $42 \mathrm{nt}$ of actin coding sequence fused to the gene for neomycin phosphotransferase. The original sources of the sea urchin $C y /$ sequences were a lambda recombinant isolated from a sea urchin genomic library (Scheller et al. 1981) and a plasmid recombinant (Durica, Schloss \& Crain, 1980). The CyI.CAT fusion gene was constructed as outlined in Fig. 1A. The HindIII site located $31 \mathrm{nt}$ upstream from the CAT ATG in the plasmid pSVO-CAT (Shott-Akhurst. Calzone, Britten \& Davidson, 1984) was changed to a Sall site by digestion with HindIII, and ligation to SalI linkers, after extension of the recessed termini with Klenow polymerase $I$. The indicated $B a m \mathrm{HI}-B c l$ I CyI fragment of pCIpN5 was subcloned into the pUC18 vector, and the BamI-BamHI 
fragment containing the remaining sea urchin sequences was then cloned into the BamHI site of this plasmid. The presence of a SalI site in the polylinker adjacent to the Bcll-BamHI ligation site made it possible to remove from this plasmid a $4.4 \mathrm{~kb}$ Sall fragment which, as shown below, contains about $2.5 \mathrm{~kb}$ of $5^{\prime}$ flanking sequence upstream of the CyI cap site. This fragment was isolated and ligated into the SalI site of the altered pSVO.CAT in the proper orientation. The resulting construct, called $\mathrm{CyI} \cdot \mathrm{CAT}$, contains the $2.5 \mathrm{~kb} 5^{\prime}$ flanking sequence, exon I of the $C y /$ gene, the entire $5^{\prime}$ leader intron and $42 \mathrm{nt}$ of actin-coding sequence derived from exon II of the gene. The fusion between the $C y I$ sequences and the CAT coding region inserted a sequence between the CyI ATG and the CAT ATG $96 \mathrm{nt}$ in length. Thus if translation were to initiate at the CyI ATG, the CAT protein would contain an additional 33 amino acids, which would not be expected to decrease the enzymatic activity of the protein (Schottel, Sninsky \& Cohen, 1984). The region between the two ATG's was sequenced to verify that the proper reading frame for the CAT protein would be initiated if translation does start at the CyI ATG, as shown in Fig. $1 B$.

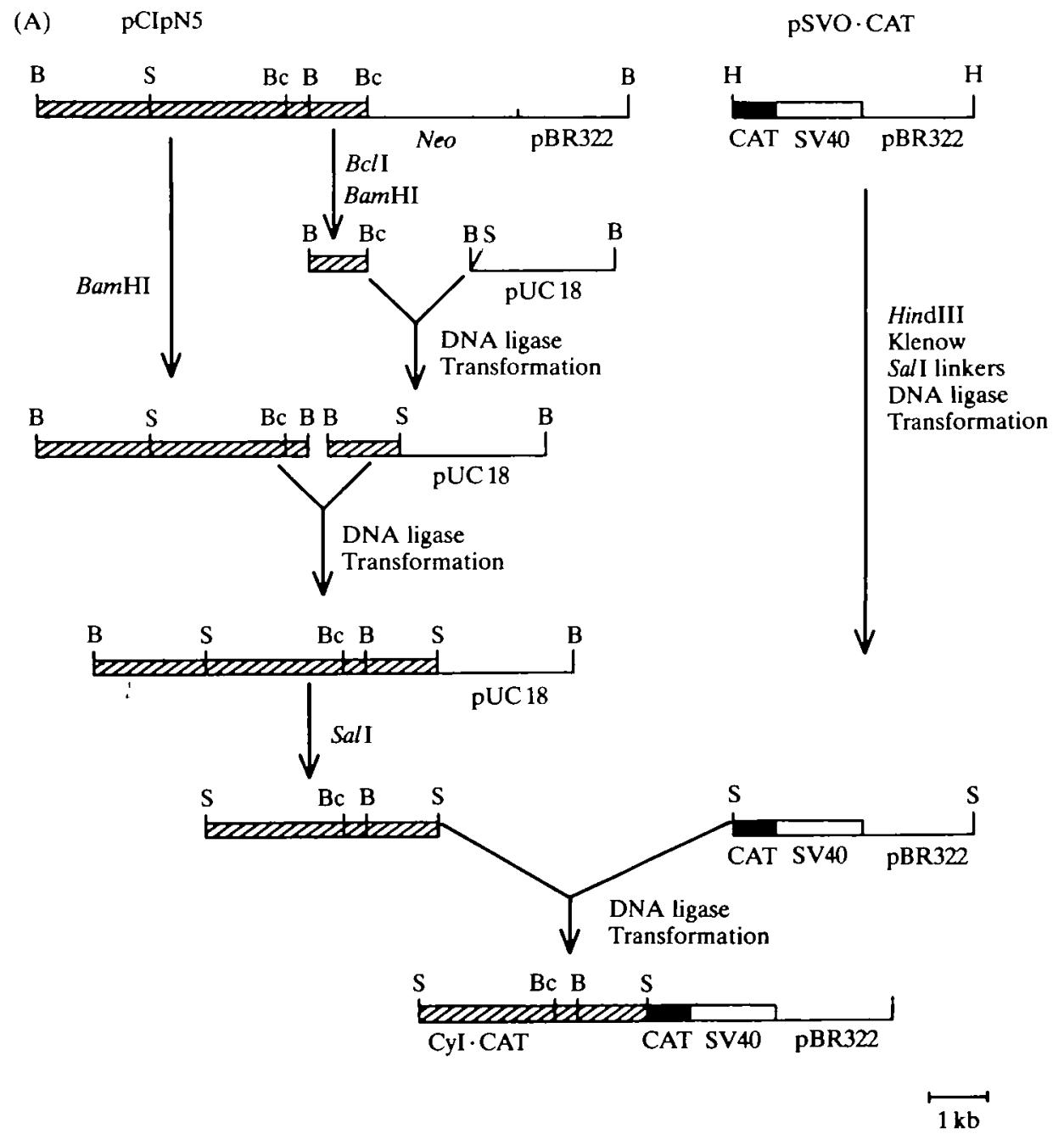

(B)

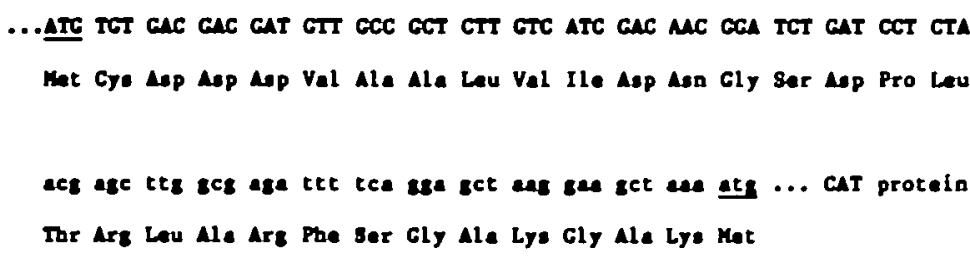

Fig. 1. Construction of the CyI CAT plasmid. (A) Flow diagram of the steps used to generate the CyI $\cdot$ CAT plasmid. The restriction enzyme sites shown are BamHI (B), Sall (S), BclI (Bc), HindIII (H). The hatched areas indicate sea urchin sequences. Details of the construction are given in Materials and Methods. (B) Sequence of the CyI C CAT junction. A small fragment containing the junction between the CyI ATG and the CAT ATG was subcloned into the vector $\mathrm{M} 13 \mathrm{mp} 10$ and sequenced. This sequence is shown along with the encoded amino acids. Capital letters represent CyI sequence and small characters the CAT sequence. 


\section{Injection of sea urchin eggs and CAT assays}

Preparation and injection of sea urchin eggs were carried out as described by McMahon et al. (1985). The fertilized eggs were cultured at $15^{\circ} \mathrm{C}$ and collected at the appropriate developmental stage by centrifugation for $5 \mathrm{~min}$ in a microfuge. The embryo pellets were taken up in $100 \mu \mathrm{l}$ of $250 \mathrm{~mm}$ Tris, pH 8.0, and to each sample approximately $150024 \mathrm{~h}$ noninjected embryos were added as carrier. The embryos were lysed by three consecutive freeze-thaw cycles using an ethanol-dry ice bath, and heating for $3 \mathrm{~min}$ at $65^{\circ} \mathrm{C}$. Half of the lysate was removed and stored at $-70^{\circ} \mathrm{C}$ for DNA determination. The remaining lysate was spun for $15 \mathrm{~min}$ in a microfuge. The supernatant was removed and assayed for CAT enzyme activity essentially as described by Gorman, Moffat \& Howard (1982), with some minor changes (McMahon, Novak, Britten \& Davidson, 1984). The final reaction, totalling $150 \mu \mathrm{l}$, contained $0.5 \mu \mathrm{Ci}$ of $\left[{ }^{14} \mathrm{C}\right]$ chloramphenicol (45 mCi mmol ${ }^{-1}$, Amersham) and $0.53 \mathrm{~mm}-$ acetyl CoA (Sigma). Bacterial CAT (Pharmacia P-L Biochemicals) was utilized to provide a standard curve. Assays were run for $2 \mathrm{~h}$ at $37^{\circ} \mathrm{C}$ and the acetylated products were separated on an Eastman Kodak silica gel TLC plate. The TLC plates were exposed to Kodak XAR5 film at $-70^{\circ} \mathrm{C}$. The calculated percent acetylation was estimated by scintillation counting of appropriate regions of the TLC assay plates. The number of enzyme units present in each sample was calculated by reference to the bacterial CAT standard curve. One unit of bacterial CAT enzyme activity represents approximately $2.6 \times 10^{11}$ molecules of relatively pure enzyme protein (McMahon et al. 1984).

\section{CAT DNA determination}

An equal volume of $0 \cdot 1 \mathrm{~m}$-EDTA Tris, $\mathrm{pH} 8.0$, containing $1 \%$ SDS was added to the other half of the lysate for each sample. Proteinase $\mathrm{K}$ was added to a concentration of $20 \mu \mathrm{g} \mathrm{ml}^{-1}$, and the samples were incubated at $55^{\circ} \mathrm{C}$ for $2 \mathrm{~h}$. Following extractions with phenol and Sevag solution, one fifth the volume was removed and diluted four times with DAPI buffer (DAPI buffer is $100 \mathrm{~mm}-\mathrm{NaCl}, 10 \mathrm{~mm}$-EDTA, $10 \mathrm{~mm}$-Tris- $\mathrm{HCl}, \mathrm{pH} 7 \cdot 0$ ). The total amount of DNA in the sample was then determined fluorometrically by the DAPI method (Brunk, Jones \& James, 1979). The remainder of the solution was brought to $0.4 \mathrm{M}-\mathrm{NaOH}$ and heated for $1 \mathrm{~h}$ at $65^{\circ} \mathrm{C}$. This treatment effectively hydrolyses the RNA in the sample and denatures the DNA. The samples were neutralized and filtered onto nitrocellulose using the Schleicher and Schuell minifold II apparatus. Prior to hybridization, the experimental slots were cut exactly in half. One half was hybridized to a uniformly labelled singlestranded RNA probe consisting of CAT gene sequences transcribed in vitro from an Sp6 vector. The other half was hybridized to a single-copy probe specific to the 3 ' noncoding trailer sequence of the $C y I$ actin gene (Lee et al. 1986), also transcribed from an Sp6 vector. This serves as a hybridization efficiency standard, since the amount of DNA present is known (see above), and there is a single $C y /$ gene per haploid genome (i.e. per $0.8 \mathrm{pg}$ of DNA). The number of CAT DNA molecules calculated per half slot was then converted to average CAT DNA molecules per embryo.

\section{Results}

\section{Structure of the CyI gene}

Though the complete nucleotide sequence of the coding region of the $C y I$ gene had been reported by Cooper \& Crain (1982), the location of the transcriptional start (cap) site, the organization of the $5^{\prime}$ end of the gene and the sequence of the $5^{\prime}$ flanking region were not known. A map of this region is shown in Fig. 2A. Restriction fragments A-D indicated on this figure were subcloned into M13 vectors and singlestranded DNA probes synthesized from these recombinants were reacted with embryo RNA and then treated with nuclease S1 (data not shown). These preliminary experiments indicated that the transcript begins in fragment $\mathrm{B}$, which on reaction with RNA yielded a short protected subfragment similar in length to the leader exon that had previously been observed in the $C y I I I a$ cytoskeletal sea urchin actin gene of S. purpuratus (Akhurst et al. 1987). This

Fig. 2. Structure of the $5^{\prime}$ end of the CyI gene. (A) Map of the gene and location of leader sequence, introns and trailer sequence. The $C y I$ actin gene is shown beneath a partial restriction map of the $\lambda-28$ (Scheller et al. 1981) genomic recombinant DNA which includes this gene. The restriction enzyme sites shown are EcoRI (R), BamHI (B), SalI (S), HindIII (H), HincII (Hc), SstI (Ss), BclI (Bc), PstI (P) and BglII (BgII). Brackets indicate restriction fragments utilized for the $\mathrm{S} 1$ analysis referred to in text. The various regions of the gene are indicated as follows: filled areas represent noncoding leader and trailer sequences of the transcript; cross-hatched areas are coding regions, and open areas are introns. The two introns within the coding region occur at amino acid $121 / 122$ and within the codon for amino acid 204 (Cooper \& Crain, 1982). The position of the poly(A) addition site was determined by Lee et al. (1986). The location of the 5 ' leader intron and start of transcription were determined in this work. (B) Genomic sequence including $5^{\prime}$ leader exon and flanking regions of the CyI gene. The sequence shown begins $351 \mathrm{nt}$ within the leader intron and extends upstream for about $1300 \mathrm{nt}$. The start of transcription is indicated at the boxed 'A'. 'CAAT' and 'TATA' sequence elements are underlined at -67 and -33 , respectively, from the start of transcription $(0)$. The area in brackets indicates a region of approximately $50 \mathrm{nt}$ that was not sequenced. The $5^{\prime}$ splice site for the leader intron, determined by comparison with a cDNA clone. is indicated by a vertical line. (C) Determination of the start of transcription by primer extension. A synthetic primer $25 \mathrm{nt}$ long and including the $B c l$ I site (see B) was labelled with ${ }^{32} \mathrm{P}$ and hybridized with poly( $\left.\mathrm{A}\right)$-containing RNA isolated from $48 \mathrm{~h}$ embryos (lane 1) or yeast tRNA (lane 2), and extended with reverse transcriptase. The samples were denatured and analysed on an $8 \mathrm{M}$ urea-10\% polyacrylamide gel. The DNA sequence ladder shown was generated using the same synthetic primer. 
fragment was labelled, and utilized as a probe to screen a $\lambda$ gt 11 library constructed from $62 \mathrm{~h}$ embryo RNA (Sucov et al. 1987). The 5' leader region of one of the four cDNA positive clones identified in this screen was sequenced and the restriction sites it contained determined by computer analysis. The presence of a unique $B c l I$ site also observed in fragment B provided a means of locating the $5^{\prime}$ leader sequence of the cDNA within this genomic DNA fragment. The primary sequence of the latter was then determined in both directions around the $B c l I$ site. This sequence is shown in Fig. 2B. Comparison with the cDNA sequences confirmed the location of these within fragment $B$ and defined the position of a $1.35 \mathrm{~kb}$ intron wholly contained within the 5 ' leader sequence. We determined the exact transcription start site by primer extension. A synthetic $25 \mathrm{nt}$ long DNA primer complementary to a region of the leader

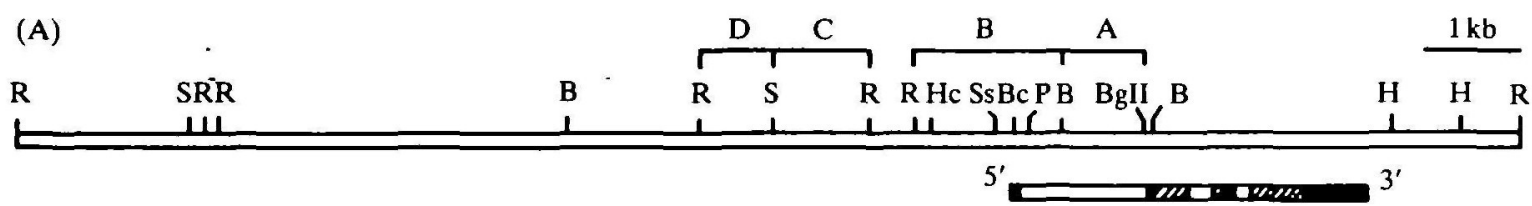

(B)
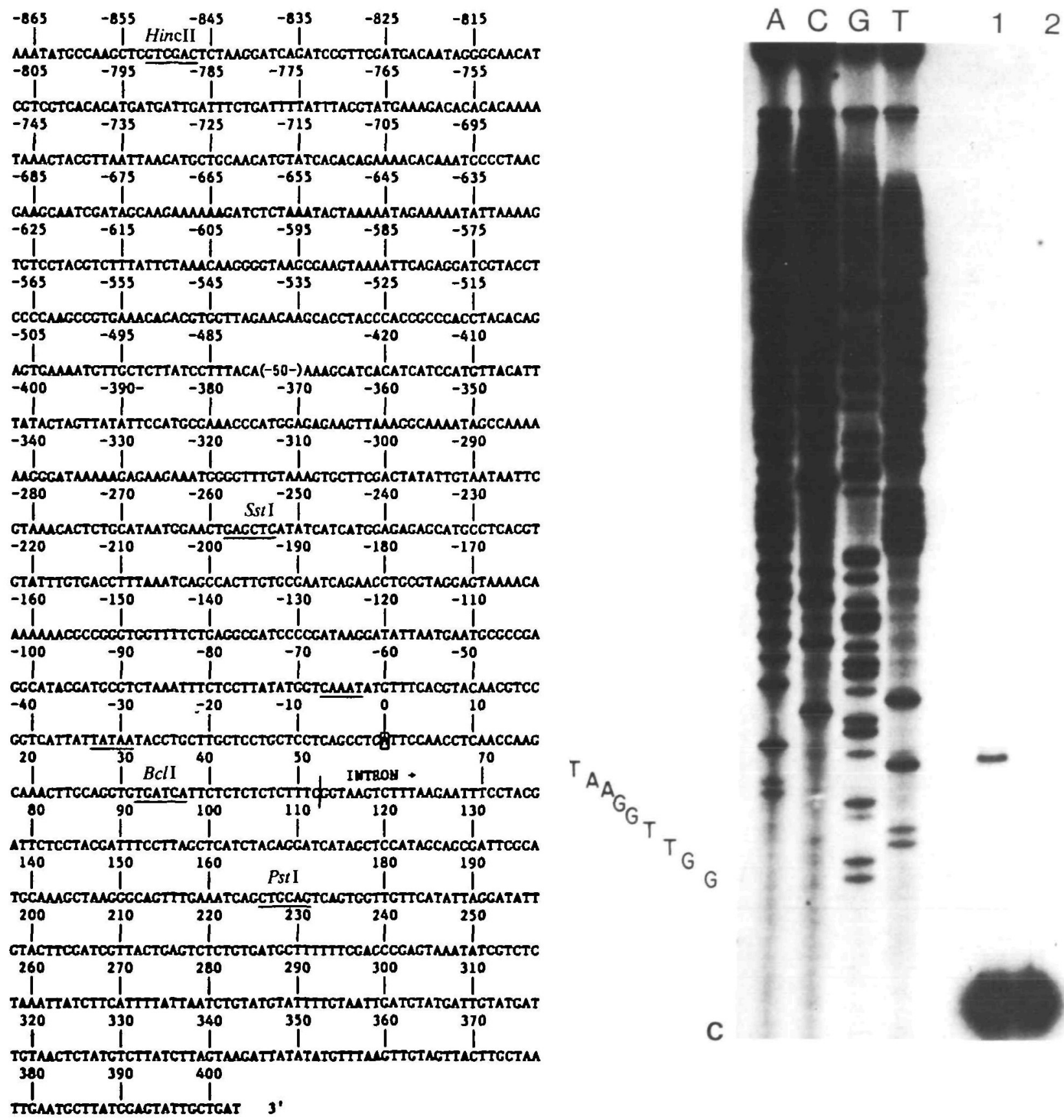


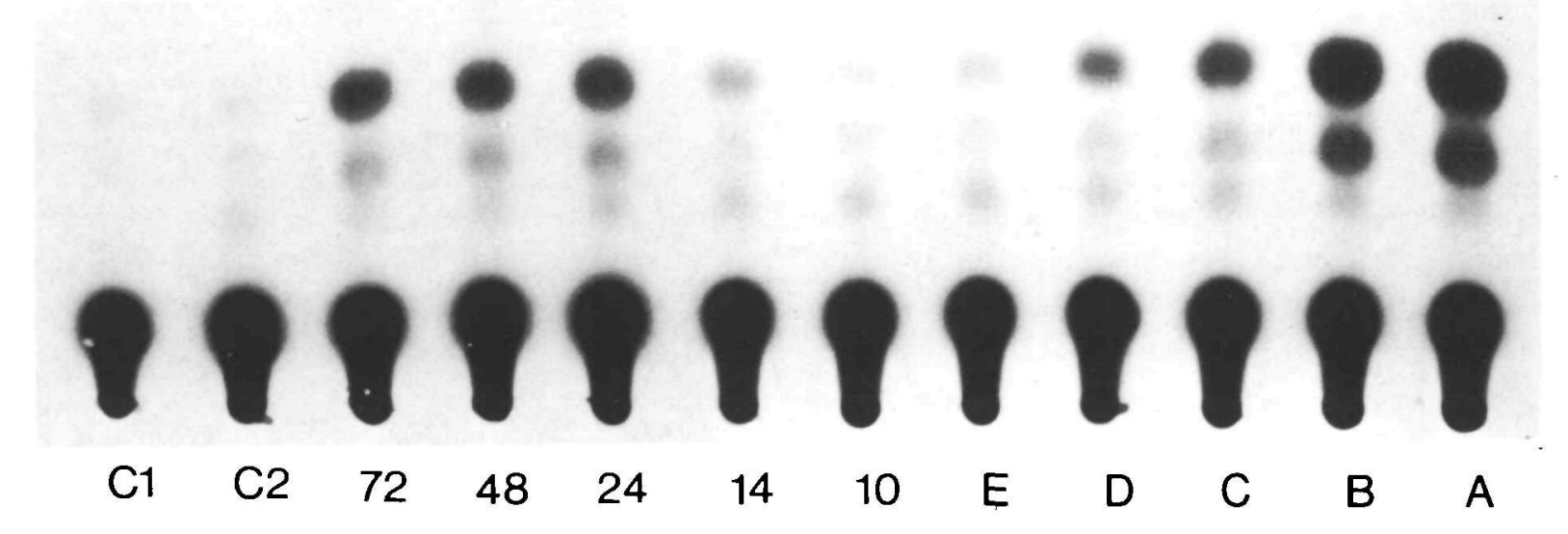

Fig. 3. Temporal expression of CyI . CAT in injected embryos. Approximately 3500 molecules per pL of linearized CyI - CAT DNA were injected into unfertilized eggs as described by McMahon et al. (1985); nominal injection vol. $2 \mathrm{pl}$. At 10, 14, 24, 48 and $72 \mathrm{~h}$ postfertilization, 75 embryos were collected and assayed for CAT activity. Bacterial CAT enzyme controls were assayed on the same TLC plate: lane A, $1 \times 10^{-3} \mathrm{U} ; \mathrm{B}, 5 \times 10^{-4} \mathrm{U} ; \mathrm{C}, 1 \times 10^{-4} \mathrm{U} ; \mathrm{D}, 5 \times 10^{-5} \mathrm{U}$; $\mathrm{E}, 1 \times 10^{-5} \mathrm{U} . \mathrm{C} 1$ is an assay using an extract from 75 uninjected embryos, and $\mathrm{C} 2$ is an assay reaction containing no extract. Data from this experiment are listed in expt. 2 of Table 1.

sequence including the $B c l$ I site was constructed and after reaction with embryo RNA the hybridization product was extended with reverse transcriptase. The result is shown in Fig. 2C, where it can be seen that the transcript begins with a sequence located $52 \mathrm{nt} 5$ from the splice site of the leader intron (see Fig. 2B). A TATAA sequence is found at -33 with respect to the cap site and a CAAAT sequence begins at position -67 . The overall structure of the gene, from this work and the prior studies carried out by Cooper \& Crain (1982) and Schuler, McOsker \& Keller (1983), is indicated below the restriction map in Fig. 2A.

\section{Temporal expression of the CyI CAT fusion gene during development}

Shott et al. (1984) showed that transcripts of the endogenous $C y I$ gene begin to accumulate between 10 and $14 \mathrm{~h}$ postfertilization (see also Durica \& Crain, 1982; Lee et al. 1986). In vivo transcription rate studies as well as nuclear run-offs carried out on the CyI gene by Lee (1986) demonstrate that in late cleavage embryos, i.e. $7 \mathrm{~h}$ postfertilization, this gene is transcriptionally silent and show that the subsequent accumulation of message can be wholly accounted for by the rate of gene transcription following activation of the gene at the early blastula stage. Thus it is clear that the endogenous $C y I$ gene is transcriptionally regulated during early development.

When the Cyl-CAT construct was injected into unfertilized eggs and development then initiated, CAT enzyme also appeared between 10 and $14 \mathrm{~h}$ postfertilization. This result is illustrated qualitatively in the CAT assay series reproduced in Fig. 3, and in Table 1 are listed four separate sets of developmental measurements in which CAT enzyme protein content was estimated from the acetylation activity recovered in the embryo lysates. Table 1 indicates that in no case is any CAT activity detectable in $10 \mathrm{~h}$ embryos and that following activation the amount of CAT enzyme achieves a level at least 5-10× the minimum detectable (see Note 2 of Table 1). In interpreting this result, it is important to realize that in sea urchin embryos CAT mRNA and CAT enzyme are unstable. The estimated half-life of the enzyme is approx. 40 min (Flytzanis et al. 1987). Thus the sharp accumulation of CAT enzyme protein after $10 \mathrm{~h}$ postfertilization indicates an increased rate of transcription and consequent increased CAT mRNA content mediated by the $\mathrm{CyI}$ regulatory sequences included in the construct.

Table 1 also presents two sets of measurements of CAT DNA carried out on samples from the same experimental embryos utilized for CAT enzyme assays. While the DNA continues to increase between 10 and $14 \mathrm{~h}$, i.e. as the embryo is completing its cleavage divisions, this increase is relatively modest. During the $10-14 \mathrm{~h}$ postfertilization interval when production and transcription of the CyI - CAT construct is initiated, the amount of CAT DNA changes only about $30 \%$, while the level of CAT enzyme increases many fold. This obviates the possibility that absence of CAT enzyme at $10 \mathrm{~h}$ results simply from the absence of adequate numbers of CAT genes at $10 \mathrm{~h}$. Two observations reported by Davidson et al. (1985) and Flytzanis et al. (1987) support the conclusion that the results shown in Fig. 3 and Table 1 indicate correct temporal regulation of the CyI - CAT fusion. First, in similar experiments utilizing a CAT gene under the control of an $\alpha$-histone promoter, appearance of CAT enzyme was observed at $10 \mathrm{~h}$ and earlier, as appropriate for the $\alpha$-histone genes, which 
Table 1. Average CAT enzyme and CAT DNA molecules per embryo*

\begin{tabular}{|c|c|c|c|c|c|c|}
\hline \multirow[t]{2}{*}{$\begin{array}{l}\text { Hours } \\
\text { postfertilization }\end{array}$} & \multicolumn{4}{|c|}{$\begin{array}{c}\text { CAT enzymet } \\
\text { Experiment }\end{array}$} & \multicolumn{2}{|c|}{$\begin{array}{l}\text { CAT DNA }+ \\
\text { Experiment }\end{array}$} \\
\hline & 1 & 2 & 3 & 4 & 1 & 4 \\
\hline 10 & ND\& & ND & ND & ND & $6.5 \times 10^{4}$ & $4.2 \times 10^{4}$ \\
\hline 14 & $5.0 \times 10^{5}$ & $7.7 \times 10^{4}$ & $2.6 \times 10^{5}$ & $4.0 \times 10^{5}$ & $8.8 \times 10^{4}$ & $5.4 \times 10^{4}$ \\
\hline 24 & $3.1 \times 10^{5}$ & $3.0 \times 10^{5}$ & $1.2 \times 10^{5}$ & & & \\
\hline 48 & $6.0 \times 10^{5}$ & $3.2 \times 10^{5}$ & $2.4 \times 10^{5}$ & & & \\
\hline 72 & & $5.4 \times 10^{5}$ & & & & \\
\hline
\end{tabular}

- Number of embryos assayed per point: expt. 1, 100; expt. 2, 75; expt. 3, 100; expt. 4, 150.

$\dagger$ The maximum amount of CAT activity that would not have been detectable was estimated from the level of background (approx. $0.1 \%$ acetylation) in assay samples recelving no extract or extract from control embryos not injected with CyI $\cdot$ CAT (see Fig. 3 ). Thus anything less than an average of about $5 \times 10^{4}$ molecules of CAT enzyme per embryo would not have been detectable. Note that only 60-80\% of injected embryos successfully incorporate exogenous DNA (McMahon et al. 1985; Flytzanis et al 1985) and thus for the successful cases average number of CAT enzyme molecules per embryo is low by this factor. CAT activity (i.e. fraction of $\left[{ }^{14} \mathrm{C}\right.$ chloramphenicol converted to monoacetylated form) was transformed to the number of enzyme molecules according to McMahon et al. (1984; see Materials and Methods).

$\$$ CAT DNA content per average embryo was obtained by slot blot hybridizations with embryo DNA with a CAT probe. with the aid of correction by an internal standard, as described in Matenals and Methods.

$\S N D$, not detectable.

are expressed at peak levels at about $10 \mathrm{~h}$ postfertilization. Therefore, lack of CyI - CAT expression at $10 \mathrm{~h}$ cannot be due to any kind of general repression of exogenously introduced DNA at this stage. Second, the number of CyI $\cdot$ CAT genes present per average embryo at $10 \mathrm{~h}$, i.e. $\geqslant 4 \times 10^{4}$ (Table 1 ), is probably already greatly in excess of the number that can be activated at any time during embryonic development. This argument has been demonstrated for CyIIIa. CAT fusion genes introduced in exactly the same manner (Flytzanis et al. 1987), and in normal midblastula stage embryos the quantity of CyIIIa mRNA is over twofold greater than the quantity of CyI mRNA (Lee et al. 1986): While we cannot yet be certain of this interpretation in respect to the behaviour of the CyI - CAT fusion, it is consistent with the observation that all four sets of embryos shown in Table 1 produce about the same maximum level of CAT enzyme and that this level remains more or less unchanged after $24 \mathrm{~h}$. It may in any case be concluded that the $2.5 \mathrm{~kb}$ of flanking sequence present in the CyI.CAT construct suffice for positive temporal regulation, on the normal CyI schedule.

\section{CyI $\cdot$ CAT deletions}

To obtain a crude map of the location of necessary cis regulatory sequences we constructed the series of deletions illustrated in Fig. 4A. Deletions $\Delta \mathrm{SHc}$, $\Delta S P$ and $\Delta$ SSs contain decreasing amounts of $5^{\prime}$ flanking sequence. $\Delta \mathrm{SSs}^{\prime}$ contains the same $C y l$ sequences as does $\Delta$ SSs except for the deletion of most of the large leader intron. The $\Delta$ SPP deletion serves as a promoterless control, as the $C y I$ sequences included begin within this intron, $170 \mathrm{nt}$ after the transcriptional start site. It should be noted that the deletions shown in Fig. 4A do not include identical amounts of plasmid sequences and the effects of this factor on the expression of the CAT fusion gene, if any, remains untested.

The deletion constructs were linearized at the $B g l \mathrm{I}$ site of the cloning vector, injected into eggs as before, and embryos harvested and analysed for CAT enzyme and CAT DNA $24 \mathrm{~h}$ after fertilization. As shown in Fig. 4B and Table 2, deletion of the outer $1700 \mathrm{nt}$ of CyI sequence decreases expression by a small amount, a factor often $<2$. Thus, in other experiments not included in Table 2 the ratios of $\Delta \mathrm{SHc} / \mathrm{CyI} \cdot \mathrm{CAT}$ activity were $0.56,0.62$ and 0.73 . This minor effect could indicate the presence of a distant sequence that potentiates $\mathrm{CyI} \cdot \mathrm{CAT}$ function, but it could also merely be an effect of changing the overall structure of the concatenates that form from the exogenous DNA within the embryo, e.g. by bringing the vector plasmid sequence closer to the transcriptional start sites. Thus Flytzanis et al. (1987) showed in a similar series of experiments with CyIIIa. CAT deletion constructs that plasmid sequences exert a mild depressive effect on CAT activity. The further deletions $\triangle \mathrm{SP}$ and $\Delta \mathrm{SSs}$ reproducibly decrease activity to around $10-20 \%$ of the CyI. CAT control (Fig. 4B). This result was obtained in three experiments in addition to that shown in Fig. 4 and Table 1. These effects cannot be attributed to differences in the amounts of exogenous DNA, since as shown in Table 1, the DNA of all of the constructs amplified to about the same extent.

The result shown in the final row of Experiment 1 of Table $2\left(\Delta \mathrm{SSs}^{\prime}\right)$ indicates that removal of all of the leader intron except for $118 \mathrm{nt}$ at the $5^{\prime}$ end and $293 \mathrm{nt}$ at the $3^{\prime}$ end does not affect the amount of CAT 
(A)

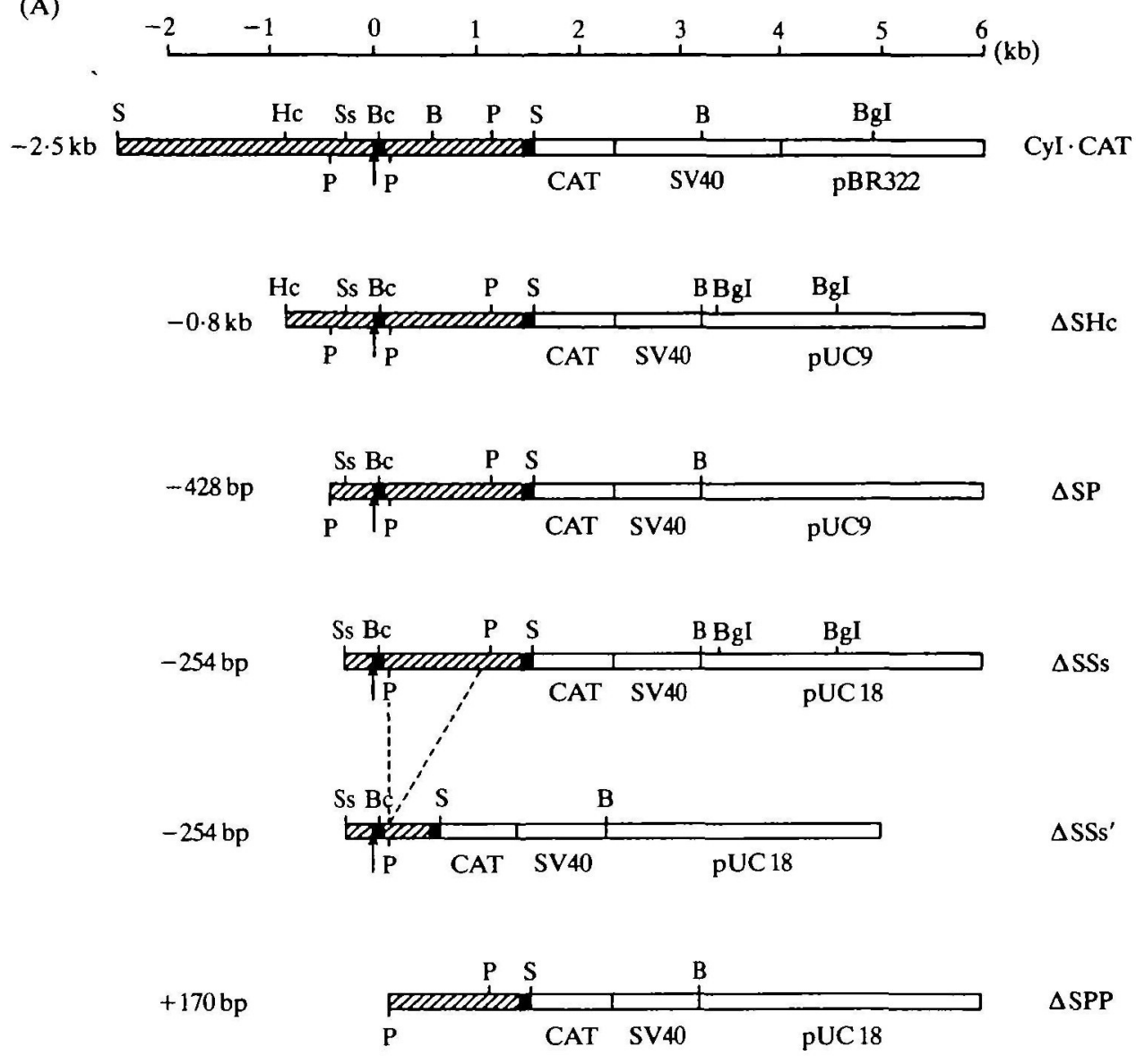

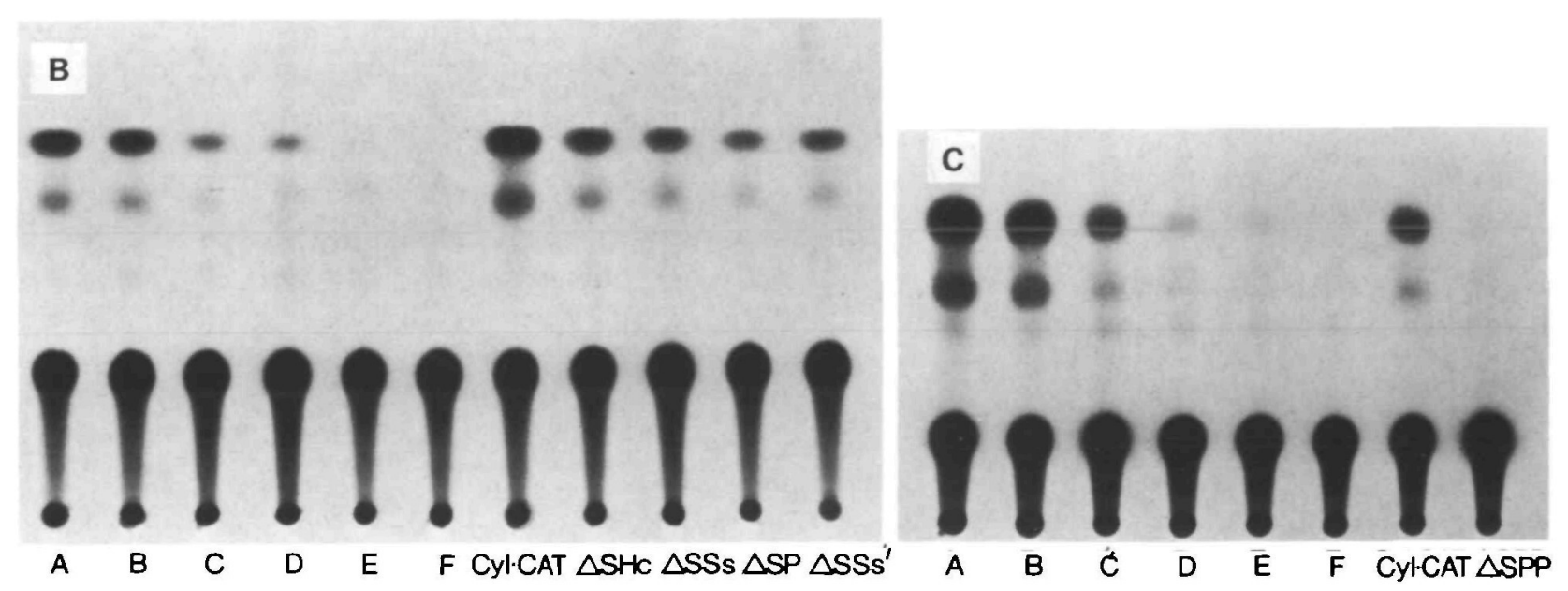

Fig. 4. Deletion constructs injected into eggs, and representative CAT assays. (A) Restriction maps of CyI CAT deletion constructs. The arrow indicates the start of transcription. $\Delta \mathrm{SSs}^{\prime}$ was derived from $\Delta S S$ s by removing the sequences indicated by the dashed lines. Hatched and filled-in areas are $C y I$ sequences: SV 40 and plasmid sequences are indicated. The filled-in regions denote, respectively, the first exon of the CyI leader sequence, and a portion of the second exon, consisting of the remained of the leader sequence plus a small amount of CyI coding region upstream of the SalI restriction site located at the junction of the CAT and sea urchin sequences (see Fig. 1). The number to the left of each diagram indicates the number of ntp upstream from the start of transcription $(0)$ remaining in the fusion construct. The restriction sites shown are: $B a m H I(B), B c l I(B c), \operatorname{HincII}(\mathrm{Hc})$, Pst $(\mathrm{P}), \operatorname{Sall}(\mathrm{S})$, and $B g l \mathrm{I}(\mathrm{BgI})$. (B) and (C), CAT assays of embryos injected with indicated deletions. Approximately 3500 molecules per pL of each construct were injected into unfertilized eggs, and at $24 \mathrm{~h}$ postfertilization 150 embryos were collected for each sample and assayed for CAT activity. Bacterial CAT enzyme controls were as follows: A, $1 \times 10^{-3} \mathrm{U} ; \mathrm{B}, 5 \times 10^{-4} \mathrm{U} ; \mathrm{C}, 1 \times 10^{-4}$ U; D, $5 \times 10^{-5} \mathrm{U}$; E, $1 \times 10^{-5}$; and F, No enzyme. Data for these experiments are shown in Table 2 (experiments 1 and 2). 
Table 2. CAT enzyme accumulation and CAT DNA per average embryo after injection of $C y I \cdot C A T$ and various other constructs*

\begin{tabular}{|c|c|c|c|}
\hline Expt. & Construct & $\begin{array}{c}\text { Av. CAT } \\
\text { enzyme } \\
\text { molecules per } \\
\text { embryo }\end{array}$ & $\begin{array}{c}\text { Average } \\
\text { CAT DNA } \\
\text { genes per } \\
\text { embryo }\end{array}$ \\
\hline 1 & $\begin{array}{c}\mathrm{CyI} \cdot \mathrm{CAT} \\
\Delta \mathrm{SHc} \\
\Delta \mathrm{SP} \\
\Delta \mathrm{SSs} \\
\Delta \mathrm{SSs}^{\prime}\end{array}$ & $\begin{array}{l}2.6 \times 10^{6} \\
6 \cdot 3 \times 10^{5} \\
2.7 \times 10^{5} \\
2.7 \times 10^{5} \\
3.3 \times 10^{5}\end{array}$ & $\begin{array}{l}5 \cdot 1 \times 10^{5} \\
2 \cdot 9 \times 10^{5} \\
3 \cdot 5 \times 10^{5} \\
3 \cdot 2 \times 10^{5} \\
3.5 \times 10^{5}\end{array}$ \\
\hline 2 & $\begin{array}{c}\text { CyI } \cdot \text { CAT } \\
\Delta \text { SPP }\end{array}$ & $\begin{array}{c}2 \cdot 8 \times 10^{5} \\
0\end{array}$ & $\begin{array}{l}5.9 \times 10^{4} \\
7.0 \times 10^{4}\end{array}$ \\
\hline $3 a$ & $\begin{array}{c}\text { CyIIIa } \cdot \text { CAT } \\
\text { CyI } \cdot \text { CAT }\end{array}$ & $\begin{array}{l}3.1 \times 10^{6} \\
7 \cdot 8 \times 10^{5}\end{array}$ & $\begin{array}{l}1.2 \times 10^{5} \\
2.5 \times 10^{5}\end{array}$ \\
\hline b & $\begin{array}{c}\text { CyIIIa } \cdot \text { CAT } \\
\text { CyI } \cdot \text { CAT }\end{array}$ & $\begin{array}{l}2 \cdot 8 \times 10^{7} \\
4 \cdot 1 \times 10^{5}\end{array}$ & \\
\hline c & $\begin{array}{c}\text { CyIIIa } \cdot \text { CAT } \\
\text { CyI } \cdot \text { CAT }\end{array}$ & $\begin{array}{l}1.8 \times 10^{6} \\
3.3 \times 10^{4}\end{array}$ & \\
\hline
\end{tabular}

* Each batch of eggs displays a different level of CAT activity, which is reproducible within the batch (Flytzanis et al. 1986; unpublished data). The experiments shown in the table were done with different batches of eggs each obtained from a single female.

enzyme generated. This experiment provides no support for the possibility that the long leader introns common to both the $C y I$ and $C y I I I a$ sea urchin actin genes (Akhurst et al. 1987) might contain regulatory sequence, though it of course does not exclude this possibility, if such elements are redundant with others located in the $5^{\prime}$ flanking sequences. The promoterless construct tested in experiment 2 of Table 1 ( $\triangle \mathrm{SPP}$ ) failed to display any activity (Fig. $4 \mathrm{C}$ ). Thus, it is very unlikely that the productive transcription observed with the other constructs could derive from cryptic promoters active within the sea urchin cells, e.g. in the plasmid or SV40 DNA sequences.

CAT synthesis from the same deletion constructs was also examined at $10 \mathrm{~h}$ of development. In no case could any enzyme activity be detected. It follows that the $254 \mathrm{nt}$ of $5^{\prime}$ flanking sequence remaining in the $\Delta$ SSs construct suffice for temporally regulated expression, albeit at a relatively low level. At least one additional positively acting cis-regulatory element must exist in the region between -408 and approx. -800 , since, as discussed, the $\Delta \mathrm{SP}$ deletion to -428 results in $80-90 \%$ decrease in activity, relative to CyI CAT.

Experiment 3 of Table 2 displays comparisons of CAT activity generated by the analogous CyIIIa . CAT construct (Davidson et al. 1985; Flytzanis et al. 1987) with that generated by CyI . CAT, after injection into the same batches of eggs. The normal ratio of CyIIIa to CyI mRNAs in the $24 \mathrm{~h}$ embryo is about $2 \cdot 7$ (Lee et al. 1986). The ratios of CAT produced from the CyIIIa construct to CAT produced from the CyI construct were approx. 4, 70 and 50 in the three experiments shown. The first of these values is probably abnormally low, due to a level of CyIIIa. CAT activity much below that usually obtained (e.g. Flytzanis et al. 1987; unpublished measurements). In any case, since CAT mRNA and protein are unstable in sea urchin cells (Flytzanis et al. 1987) these results suggest a significant difference in the fusion gene promoter activities, much exceeding the respective difference in the endogenous CyI and CyIIIa gene promoters (Lee et al. 1986; Lee, 1986). One possible explanation is that additional positively acting control elements are located elsewhere than within the $2.5 \mathrm{~kb}$ of $5^{\prime}$ flanking sequence included in the CyI. CAT construct.

\section{Discussion}

Regulatory activity of exogenous gene sequences injected into sea urchin eggs

These results demonstrate that cis-regulatory sequences of a second actin gene are capable of directing correct temporal activation of a reporter CAT coding sequence in the developing sea urchin embryo. As reviewed above, upstream sequences of the CyIIIa actin gene suffice to regulate both spatial and temporal embryonic expression of a similar fusion construct. The cis-regulatory sequences of the $\mathrm{Cyl}$ actin gene that are responsible for its activation in the blastula stage embryo must interact with at least a partially different set of trans-activator molecules, since $C y I$ expression occurs in different cells than does CyllIa expression (see Introduction).

Regulatory sequences of at least eight different sea urchin genes have now been shown to function during embryonic development when injected into unfertilized eggs. These are the early $H 2 a$ gene (Davidson $e t$ $a l .1985$ ); the early $H 2 b$ and late $H 2 b$ genes (R. Maxson, personal communication); the Spec1 gene coding for a $\mathrm{Ca}^{2+}$-binding protein (W. Klein, personal communication); the CyIIIa actin gene (Davidson et al. 1985; Flytzanis et al. 1987) and the Cyl actin gene (this work), all of $S$. purpuratus. The $S$. purpuratus CyIIIa actin gene regulatory sequences have also been found to function on the correct timetable when CyIIIa.CAT is injected into Lytechinus variegatus eggs, i.e. when the host embryos attain the equivalent early blastula stage. At the higher temperature of culture $\left(22^{\circ} \mathrm{C}\right)$, this occurs several hours prior to the time when the CyIIIa gene is activated in S. purpuratus embryos (R. Franks et al, unpublished data). In addition, L. Vitelli (personal communication) 
showed that an injected sperm $\mathrm{H} 2 \mathrm{~b}$ histone is not transcribed at all in the embryo, again as expected on the premise of faithful regulation, since this gene is not utilized except during spermiogenesis. Except for the late $H 2 b$ histone gene (and of course the sperm histone gene) the genes so far examined for activity after injection into the egg are normally all transcribed at maximal rates early in development, i.e. by the blastula stage. It remains to be determined whether other genes that are ontogenically activated at much later stages will also be expressed appropriately on injection into sea urchin eggs. Since incorporation of exogenous DNA after cytoplasmic injection tends to occur in a mosaic fashion (Flytzanis et al. 1985; Hough-Evans et al. 1987), the response observed in such cases might be quantitatively less impressive. Nonetheless, it is now evident that, at least for genes utilized early on, the cytoplasmic gene transfer system of McMahon et al . (1985) provides an excellent functional test system for the examination of gene regulation in early sea urchin development.

The deletion constructs provide a coarse localization of $C y I$ regulatory sequences

Unlike the CyIIIa gene, the $C y I$ gene is functional in various adult tissues as well as in the embryo (Shott $e t$ al. 1984) and the present studies provide no evidence as to the location of the sequences required for adult expression. The location of at least some of the regulatory sequences required for blastula stage activation is indicated on a coarse scale by the deletion experiments summarized in Fig. 4 and Table 2. We find that inclusion of a $254 \mathrm{nt}$ sequence $5^{\prime}$ from the transcription initiation site suffices for temporally correct, though low-level expression. An additional positively acting element or elements apparently exist(s) between -428 and -800 and, as discussed in Results, there may be other cis-active sequences not included in the CyI. CAT construct. Several short sequence elements lying within the region between +1 and -254 display homology with $5^{\prime}$ sequence elements of the CyIIIa gene, though overall the upstream sequences of these two genes are wholly dissimilar (Akhurst et al. 1987). Since CyIIIa and CyI are activated at about the same time, these shared sequence elements could be functional, but since they are activated in different sets of cells there are likely to be other distinct positive or negative regulatory sequences in addition. At least eight sites at which proteins bind specifically to upstream regions of CyIIIa DNA have now been identified (Calzone et al. 1987; unpublished data). Much additional analysis, utilizing both in vitro DNA-protein interactions and the gene transfer system applied in this study, will be required before the particular cis-regulatory sequences responsible for spatial and temporal activation of the CyIIIa and $C y I$ actin genes can be identified.

In a more general sense, this work contributes to the body of experimental evidence suggesting that activation of genes in the early embryo is mediated by cis-trans interactions. Such is the direct implication of the now multiple observations that exogenous sequences introduced into embryo nuclei in abnormal numbers of copies, and undoubtedly in abnormal positions, are nonetheless activated at the proper developmental stages. For CyIIIa. CAT the exogenous regulatory sequences have been shown to suffice as well for correct spatial expression (Hough-Evans et al. 1987), as would be expected on the assumption of regulation by cis-trans interactions. The simple consequence is that the spatial pattern of activation of genes that begin to be expressed in the early embryo must reflect the regional presentation or activation of their trans regulators. For genes such as $C y I$ and $C y I I I a$ this is now a testable theory that could constitute an explanation of the means by which genomic information begins to be differentially expressed in the various cells of the early embryo.

We thank Michael Graham, an undergraduate research assistant, for his work on this project. Dr Constantin Flytzanius constructed the clone $\mathrm{pC} 1 \mathrm{pN} 5$ and we are grateful to him for making it available to us. This research was supported by NIH grant GM-02927. K.S.K. was supported by an NIH postdoctoral training grant (HD07257)

\section{References}

Akhurst, R. J., Calzone, F. J., Lee, J. J., Britten, R. J. \& Davidson, E. H. (1987). Structure and organization of the CyIIIa actin gene subfamily of the sea urchin, Strongylocentrotus pupuratus. J. molec. Biol. 194, 193-203.

Angerer, R. C. \& Davidson, E. H. (1984). Molecular indices of cell lineage specification in the sea urchin embryo. Science 226, 1153-1160.

Berk, A. J. \& Sharp, P. A. (1977). Sizing and mapping of early adenovirus mRNAs by gel electrophoresis of S1 endonuclease-digested hybrids. Cell 12, 721-732.

Brunk, C. F., Jones, K. C. \& J James, T. W. (1979). Assay for nanogram quantities of DNA in cellular homogenates. Anal. Biochem. 92, 497-500.

Calzone, F. J., Flytzanis, C. N., Fromson, D. R., Britten, R. J. \& Davidson, E. H. (1987). ProteinDNA interactions within regulatory regions required for embryonic activation of the sea urchin CyIIIa actin gene. In Molecular Approaches to Developmental Biology (ed. R. A. Firtel \& E. H. Davidson), pp. 205-221. New York: Alan R. Liss. 
Cooper, A. D. \& Crain, W. R. (1982). Complete nucleotide sequence of a sea urchin gene. Nucleic Acid Res. 10, 4081-4092.

Cox, K. H., Angerer, L. M., Lee, J. J., Britten, R. J., Davidson, E. H. \& Angerer, R. C. (1986). Cell lineage-specific programs of expression of multiple actin genes during sea urchin embryogenesis. J. molec. Biol. 188, 159-172.

Davidson, E. H., Flytzanis, C. N., Lee, J. J., Robinson, J. J., Rose, S. J. \& Sucov, H. M. (1985). Lineage-specific gene expression in the sea urchin embryo. Cold Spring Harb. Symp. Quant. Biol. 50, 321-328.

Durica, D. S. \& CRAIN, W. R. (1982). Analysis of actin synthesis in early sea urchin development. Devl. Biol. 92, 428-439.

Durica, D. S., Schloss, J. A. \& Crain, W. R. (1980). Organization of actin gene sequences in the sea urchin: Molecular cloning of an intron-containing DNA sequence coding for a cytoplasmic actin. Proc. natn. Acad. Sci. U.S.A. 77, 5683-5687.

Flytzanis, C. N., McMahon, A. P., Hough-Evans, B. R., Katula, K. S., Britten, R. J. \& Davidson, E. H. (1985). Persistence and integration of cloned DNA in postembryonic sea urchins. Devl. Biol. 108, 431-442.

Flytzanis, C. N., Britten, R. J. \& Davidson, E. H. (1986). Expression of a cytoskeletal actin fusion gene following transfer into sea urchin embryos. In Gametogenesis and the Early Embryo (ed. J. G. Gall), pp. 271-281. New York: Alan R. Liss.

Flytzanis, C. N., Britten, R. J. \& Davidson, E. H. (1987). Ontogenic activation of a fusion gene introduced into the sea urchin egg. Proc. natn. Acad. Sci. U.S.A. 84, 151-155.

Gorman, C. M., Moffat, L. F. \& Howard, B. H. (1982). Recombinant genomes which express chloramphenicol acetyltransferase in mammalian cells. Molec. cell. Biol. 2, 1044-1051.

Hough-Evans, B. R., Franks, R. R., Cameron, R. A., Britten, R. J. \& Davidson, E. H. (1987). Correct cell type-specific expression of a fusion gene injected into sea urchin eggs. Devl. Biol. 121, 576-579.

Hu, N.-T. \& Messing, J. (1982). The making of strandspecific M13 probes. Gene 17, 271-277.

LEE, J. J. (1986). The genomic organization and expression of the Strongylocentrotus purpuratus actin gene family. Ph.D. Thesis, California Institute of Technology, Pasadena, CA.

Lee, J. J., Shott, R. J., Rose, S. J., Thomas, T. L., Britten, R. J. \& Davidson, E. H. (1984). Sea urchin actin gene subtypes: Gene number, linkage, and evolution. J. molec. Biol. 172, 149-176.
Lee, J. J., Calzone, F. J., Britten, R. J., Angerer, R. C. \& Davidson, E. H. (1986). Activation of sea urchin actin genes during embryogenesis. Measurement of transcript accumulation from five different genes in Strongylocentrotus purpuratus. J. molec. Biol. 188, 173-183.

McMahon, A. P., Novak, T. J., Britten, R. J. \& Davidson, E. H. (1984). Inducible expression of a cloned heat shock fusion gene in sea urchin embryos. Proc. natn. Acad. Sci. U.S.A. 81, 7490-7494.

McMahon, A. P., Flytzanis, C. N., Hough-Evans, B. R., Katula, K. S., Britten, R. J. \& Davidson, E. H. (1985). Introduction of cloned DNA into sea urchin egg cytoplasm: Replication and persistence during embryogenesis. Devl. Biol. 108, 420-430.

Messing, J., Crea, R. \& Seeburg, P. H. (1981). A system for shotgun DNA sequencing. Nucleic Acid Res. 9, 309-321.

SAnGer, F., Nicklen, S. \& Coulson, A. R. (1977). DNA sequencing with chain-terminating inhibitors. Proc. natn. Acad. Sci. U.S.A. 74, 5463-5467.

Scheller, R. H., McAllister, L. B., Crain, W. R., Durica, D. S., Posakony, J. W., Thomas, T. L., Britten, R. J. \& Davidson, E. H. (1981).

Organization and expression of multiple actin genes in the sea urchin. Molec. cell. Biol. 1, 609-628.

Schottel, J. L., Sninsky, J. J. \& Cohen, S. N. (1984). Effects of alterations in the translation control region on bacterial gene expression: Use of CAT gene constructs transcribed from the lac promoter as a model system. Gene 28, 177-193.

Schuler, M. A., McOsker, P. \& Keller, E. B. (1983). DNA sequence of two linked actin genes of sea urchin. Molec. cell. Biol. 3, 448-456.

Shott, R. J., Lee, J. J., Britten, R. J. \& Davidson, E. H. (1984). Differential expression of the actin gene family of Strongylocentrotus purpuratus. Devl. Biol. 101, 295-306.

Shott-Akhurst, R. J., Calzone, F. J., Britten, R. J. \& Davidson, E. H. (1984). Isolation and characterization of a cell lineage-specific cytoskeletal actin gene family of Strongylocentrotus purpuratus. In Molecular Biology of Development, UCLA Symposium Molecular and Cellular Biology 19 (ed. E. H. Davidson \& R. A. Firtel), pp. 119-128. New York: Alan R. Liss.

Sucov, H. M., Benson, S., Robinson, J. J., Britten, R. J., Wilt, F. \& Davidson, E. H. (1987). A lineagespecific gene encoding a major matrix protein of the sea urchin embryo spicule. II. Structure of the gene and derived sequence of the protein. Devl. Biol. 120, 507-519.

(Accepted 10 July 1987) 
